\section{Open access: let's go for gold}

The report from the independent Finch group in the United Kingdom recommends a 'gold' route to open-access papers, in which journals impose pre-publication charges, over a 'green' route, in which manuscripts are made available through a repository (see Nature 486, 439; 2012). As secretary to the Finch committee that authored the report, I can explain why we believe that gold is the way forward as the main vehicle for publishing research.

Open access by the green route is permitted only after an embargo period, and only to an unpublished version of the paper, without links or semantic enrichment for web applications. Rights of use and re-use are severely restricted. Commercial and not-forprofit journals that rely on subscriptions impose these constraints to protect their income. Green open access without any restrictions cannot work alongside subscriptionbased publishing.

Gold open access avoids these problems: journals receive their revenues up front, so they can provide immediate access free of charge to the peerreviewed, semantically enriched published article, with minimal restrictions on use and re-use. For authors, gold means that decisions on how and where to publish involve balancing cost and quality of service. That is how most markets operate, and ensures that competition on quality and price works effectively. It is also preferable to the current, non-transparent market for scholarly journals.

The main barrier to gold open access has been a lack of systematic payment arrangements for articlepublishing charges. The UK research councils should follow the Wellcome Trust in providing straightforward and flexible payment mechanisms. The costs would represent a small rounding error set against current levels of expenditure on research.

Green open access may be cheaper, but that is not the point: watching your favourite football team playing live beats seeing the highlights later on television.

Michael Jubb Research Information Network, London, UK. michael.jubb@researchinfonet.org

\section{Open access: a green light for archiving}

The Finch report (see Nature

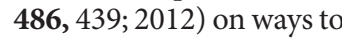
achieve universal open access to scientific papers favours a 'gold' approach that involves a publication charge for authors. This must not stand in the way of 'green' self-archiving of open-access journal articles (see go.nature.com/gvjwiw).

Research institutions and funders need to mandate green open-access self-archiving of the final, refereed versions of all journal articles as soon as they are accepted for publication.

Paying for gold open access pre-emptively today, without funders or institutes having first mandated green open access, will delay universal access and waste scarce resources. The money to pay for gold openaccess publishing will become available once green open access has eventually made subscriptions unsustainable. Stevan Harnad University of Quebec at Montreal, Canada, and University of Southampton, UK. harnad@ecs.soton.ac.uk

\section{Data sharing is harder to reward}

Open science has won another powerful advocate in the UK Royal Society (Nature 486, 441; 2012). But freely sharing research results can have social repercussions that may be damaging to science.

By confusing the allocation of scientific merit and potentially undermining authorship conventions (see, for example, T. Rohlfing and J.-B. Poline NeuroImage 59, 4189-4195; 2012), data sharing could work against individual scientists' need for recognition. This is one reason why scientific institutions, from universities to research councils, do not reward data sharing.

Policy-makers need to remember that, right or wrong, competition has always been a strong driver of science.

Gerrit Hirschfeld German Paediatric Pain Centre, Children's and Adolescents' Hospital, Datteln, Germany.g.hirschfeld@ kinderklinik-datteln.de

\section{Costa Rica pioneers ecosystem services}

As the world waits to see how the United States and China respond to the prevailing environmental, social and economic crises, the small country of Costa Rica can offer some sizeable lessons.

Costa Rica has been pioneering a green economy for 15 years through its Payments for Environmental Services (PES) programme. Under this scheme, landowners who maintain environmental services are rewarded by the people who benefit from them. For example, payments are levied from water users to pay highland landowners who keep the water flowing downstream by planting and protecting forests.

The country's 1996 Forest Law strengthened regulations for existing forests, defined ecosystem services, clarified property rights to allow trading of environmental services, and created the National Forestry Financing Fund (FONAFIFO) to oversee PES payments. Funds are drawn from taxes on fossil fuels and on water.

Voluntary payments by individuals to a national bank offset vehicle emissions. People can also use a 'green' debit card that transfers $10 \%$ of the bank's commission to FONAFIFO.

Costa Rica's commitment to becoming carbon-neutral by 2021 is encouraging local voluntary agreements and parallel schemes such as PSA Solidario (go.nature.com/4lto1s), which rewards small-scale farmers who conserve forests but cannot access the national programme. Ina Porras International Institute for Environment and Development, London, UK. ina.porras@iied.org

\section{Sewage recycles antibiotic resistance}

Your discussions on toilet technology (Nature 486, 185; and Nature 486, 186-189; 2012) should have mentioned an important aspect of sewage disposal - the problem of contamination with antibiotics and antibiotic-resistant organisms.

Processes for treating waste water provide perfect mixing pots for bacteria carrying genes that confer antibiotic resistance. These genes can come from many environmental sources and are often conveyed on mobile genetic elements. Ways must be urgently sought to prevent the genetic recycling and dispersal of antibiotic-resistance genes and of resistant organisms.

Julian Davies University of British Columbia, Vancouver, Canada.

jed@mail.ubc.ca

\section{CORRECTION}

The Obituary for David Sayre

(Nature 484, 38; 2012)

incorrectly implied that he

suggested focusing $X$-rays using Fresnel zone plates. In fact, his contribution was the use of nanofabrication to make the plates. 